\title{
DER ACCUSA'TIVUS QUALITATIS IM HEUTIGEN ENGLISCH.
}

Die granmatiker (z. b. Nätzner $\mathrm{II}^{2}, 173 \mathrm{ff}$., Schmitz $4,154 \mathrm{f}$., I. Schmidt $\left.{ }^{3}, 399\right)$ erwähnen einen in der heutigen sprache, namentlich conversationssprache, selir thlichen gebrauch des accusativs nicht. Ich begnitge mich damit denselben durch eine anzahl von stellen aus prosawerken ${ }^{1}$ unseres jahrhnnderts zu belegen: weitere beobachtung wird lehren, wie weit ihnliches schon frther vorkam, und wie weit etwa einzelne schriftsteller diesen accusativ meiden. Ith gebe meine beispiele in drei sich von selbst ergebenden abteilungen: in der ersten erscheint der accusativ prädicativ hei dem verbnm substantivum und dgl., in der zweiten prädicativ oder factitiv bei verben mit doppeltem accusativ, in der dritten attributiv bei nominen.

\section{I.}

1. age.

When $I$ was your age, I was broken-hearted in every port. Jerrold, Retired from Business 37. - My eldest girl is the same age as yours. Oliphant, At his Gates 2, 2 (A). - It must have been a sad blow for the old father to bear. I don't know why I call him old, though. What age is he? Yates, Wrecked in Port 2, 21 (T). - He [Prince Alberl] was nearly her own age, the Queen being the elder by three months and lwo or three days. Me Carthy, History 1, 112 (T). - He might lie any age, from five and thirly to five and forty. Besant and Rice, Golden Butterfly 1,30 (T). - He was very neasly the same age as herself. Ebenda 1, 219. - He looked now to be more than his age. Thackeray, Newcomes 4, 251 (T). - Pray, Lncle Phineas, do $I$ look my age? John Halifax 211. - She was still a young

I Ich ohabe mich meistens der ausgaben in den sammlungen von Tauchnitz (T) und Asher (A) bedient. 
woman, and she looked even younger than her age. Collins, Armadale 45. - 'Humphrey, what age do we feel?' - 'Thirty. Not a month more'. B. a. R. G. B. 1, 63.

\section{2. height.}

I was thick in trouble, but somehow that little fairy - she wasn't this height when Molly went - she seemed to pull me through. Jerr. Ret. 34. -- A man I have knonn since he was that height! Oliph. At h. G. 1, 130. - She was a good inch taller than either of the Twins, who, indeed, were exactly the same height. B. a. R. G. B. 1, 192.

\section{3. breadth.}

A narrow shady little walk, which ran parallel with the broad green path, but was not half its breadth. Yates, Nobody's Fortune 2, 169 (T).

\section{4. width, 5. length.}

Her dresses were neither the right width or length, nor even of the right material. Norton, Lost and Saved 1, 52 (T).

\section{6. colour.}

Her hair is nearly the colour of mine. Coll. Arm. 437. Her hair jeels so soft ... What colour is it? J. H. 293. - Her hair was a bad colour. Brooks, Sooner or Later 1, 89 (T). The grass was the colour of mud, and the trees like untanned leather. Oliph. At h. G. 1, 104. - His cheek was the colour of ashes. J. H. 323. - She turned the colour of a July rose. Ebenda 398. - The little maid grew the colour of her swain's peonies. Ebenda 196. - Vgl. I am quite sure I change colour, and become a dull grey, like a chameleon taken off the green grass and put down upon brown gravel. N. L. a. S. 1,67. - Mr. Jagenul's door was painted a dark brown. B. a. R. G. B. 1, 74.

\section{7. temper.}

That animal is as sweet a temper as you'd wish to have in a horse. Braddon, Run to Earth 2, 33 (T).

\section{8. profession.}

So you haven't made up your mind yet what profession you're going 10 be when you grow up, Bobby? Punch 1881, I, 108.'

1 Ein wodernes beispiel fiir trade fehlt mir. Vgl. aber what trade arl thou (are you)! bei Shakespeare, Cas. 1, 1, 5. 9. 12. 16 und H. IV, 


\section{9. business.}

What business do you think that Mr. Charles is? J. H. 52.

10. use.

I should just like to know what use thistles are in the world. Bulwer, My Novel 1,12(T). - What use would a thing like this be to you? Anstey, Vice Versa 18 (A). - Non, it's no use, Mr. Caudle, your beginning to talk loul. Jerrold, Curtain Lectures 93. - Now it's no use you're bouncing about in that fashion. Ebenda 97. - It's no use your turning and turning about in that way. Ebenda 99. It's no use wishing, none ut all. Ebenda 110. - It's no use talking to him. Mac Donald, Ann. of a Quiet Neighbourhood 1, 174 (T). $I$ know that it is no use dallying any longer. Y. N. F. 1, M. Use findet sich so ansserordentlich lïufig gebraucht.

\section{1. good.}

Do you think its any good? D. Chr. Murray, Model Father 99 (A). - It was no good attempting to do any more that night. Y. N. F. 1, 219. - It is no good going any closer to it than that. Ebenda 2, 278. - Ebenfalls sehr baufig.

\section{2. consequence.}

I felt inclined to ask who Mr. Mannion was and what consequence it could possibly be to me that he had come back. Collins, Basil 111 (T).

\section{II. \\ 1. size.}

... which habit of yours is what makes you the size you are. N. L. a.S. 1, 62 (gehört wegen the size you are zugleich unter I).

$$
\text { 2. colou r (vgl. I, 6). }
$$

Lord Ticehurst, whom the avoval and the unusual fhux of words rendered a bright peony colour, glared at his Mentor in nervous trepidation. Yates, Rock Ahead 2, 75 (T).

\section{3. temper (vgl. I, 7).}

$I$ found him [ein pferd namens Niagara] as fine a temper as any horse $I$ ever rode. Bra. R.t. E. 2, 77.

B. 3, 2, 160. Riechelmann's erklïrung der ersten stelle (trade $=$ tradesman, abstractum pro concreto) scheint mir verfehlt. Al. Schmidt merkt an 'whal trade fiir of whal trude'. Wright hat keine note, was wol einem modernen beispiel gleich zu achten ist. 
4. temperament.

I always thought her rather a cold temperament. Coll. B. 264.

III.

1. age (vgl. I, 1).

She leaned on the arm of a gentleman, double ber age. Smedley, Lewis Armdel 203. - A retiring, shy lad, wanting in the attributes of popularity, but said to be wondrous clever 'with his head', and to know more than people double his age. Y. R. 1, 80. - I should always have set uncle down as marrying, someone more his own age. Y. Wr. 2, 57.

\section{2. shape.}

As the young ladies stood on the broad flight of steps at the hall door, un antique figure drew nigh - an old lady, the shape of an egg, so short and stout was she. Reade, WomanHater 2, $53(\mathrm{~T})$. - Ein zweites beispiel unter 4.

$$
\text { 3. size (vgl. II, 1). }
$$

These are models of various extinct animals, the size of life. Waddy, English Echo 47. - Just look at the cows! I'm sure I've seen some at Hampstead twice the size. Y. R. 1, 239.

$$
\text { 4. colour (vgl. I, } 6 \text { und II, 2). }
$$

Next to him sat a fal, heavy-headed, large-jowled man, with a face the shape and colour of an ill-baked quartern loaf. Y.R. 2,39. - This morning she wore a morning costume, all one colour, and I think it was gray, but am not quite certain. B. a. R. G. B. 1, 70. - There was a large tank filled with water the colour of pea-soup. Grenville: Murray, Six Months in the Ranks $25(\mathrm{~T})$. - She extended a hand the colour of cream. Reade, Peg Woffington 191 (T). - He had a muddy complexion, hair the colour of dirt, a long nose, a hatchet face, mean little eyes, and was evidently not a gentleman. R. W. H. 1,150. - Vgl. 'By whal right', asked Basset, with his face a chalky grey, and all his fealures Iwitching, 'by what right do you pretend to assume the guardiunship of my daughter?' Murr. M. F. 186.

BERLIN.

J. ZUPITZ.A. 